\title{
AIKUISKASVATUKSEN VUODEN 2004 TIEDEARTIKKELI
}

$\mathrm{O}$

lli-Jukka Jokisaaren artikkeli ”Elinikäinen oppiminen - häpeä ja menetetty vapaus" on suomenkielisten tiedeartikkeleiden maailmassa uniikki, mielenkiintoinen avaus meillä vähän tunnetun ajattelijan Günther Ander$\sin$ (1902-1992) tekniikan filosofiaan. Se tuo suomalaiseen - muuten niin anglo-amerikkalaisen hegemonian läpäisemään - kasvatustieteelliseen sekä aikuiskasvatusta ja elinikäistä oppimista koskevaan keskusteluun eurooppalaisen näkökulman, joka kielitaidollisista syistä jäisi meillä marginaaliin tai vain harvojen yksinoikeudeksi.

Jokisaari ei tyydy kuitenkaan vain tuomaan Andersin ajattelua ihmisen kahdesta, keskenään ristiriitaisesta puolesta tunnetuksi, vaan hän sekä pyrkii että kykenee tekemään Andersin ajattelun pohjalta omaperäisiä tulkintoja.

Elinikäistä oppimista on pidetty ihmisyksilön positiivisena kykynä kehittää itseään sisä- ja ulkosyntyisten tarpeiden mukaan. Filosofi Günther Andersin tekniikan filosofian, tekniikan kritiikin ja myöhäismodernin ihmisen tilan analyysin kautta voidaan elinikäinen oppiminen nähdä myös radikaalisti toisella tavalla. Anders on tutkinut ja tarkastellut ihmisenä olemisen muutosta teknistyvässä maailmassa. Anders puhuu ihmisen sisään rakentuneesta häpeästä, jonka aiheuttama identifikaatiohäiriö johtuu ihmisen kahden taustan, luontominän ja teknologiaminän, välisestä sovittamattomasta ristiriidasta.
"Myöhäismoderneissa yhteiskunnissa keskeiseksi päämääräksi on tullut järjestelmä itsessään (teknologia) ja yksilöistä sen välineitä”, Jokisaari kirjoittaa. Hän jakaa monien ajattelijoiden huolen autonomian mahdollisuuksien häviämisestä, mikä liittyy autonomisen persoonan ajatukselle perustuvan yhteiskunnan katoamiseen.

Elinikäisen oppimisen ul-

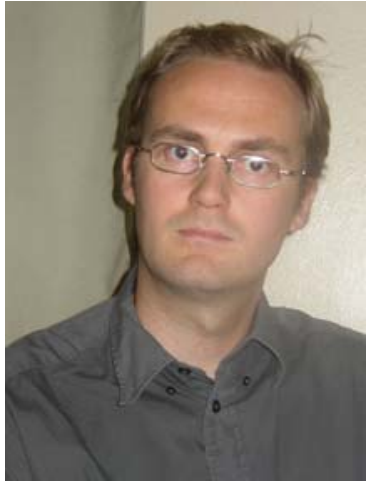

Olli-Jukka Jokisaari koisten vaatimusten edessä yksilö kokee jatkuvaa kyvyttömyyttä suhteessa vaadittuun täydellisyyteen. Jokisaari näkee häpeän toteutuvan alistuneisuutena, jolloin autonomian mahdollisuutensa menettäneenä hän pyrkii sokeasti sopeutumaan teknokratiaan. "Autonomian mahdollisuuden menettäminen teknokratiassa tarkoittaa tekniikan kautta määräytymistä, teknonomiaa”, Jokisaari toteaa.

Teoreettis-filosofisen luonteensa vuoksi artikkeli on vaativa, mutta se palkitsee ruhtinaallisesti vaivannäön tuomalla elinikäisen oppimisen keskusteluun uuden, oivaltavan, ihmisen luonnosta lähtevän näkökulman.

Kirjoittajan kieli on sujuvaa ja iskevää ja hänen ajattelunsa on selkeä ja kirkas. 